\title{
ARCHITECTURE AND NATION BUILDING IN THE AGE OF GLOBALIZATION: CONSTRUCTION OF THE NATIONAL STADIUM OF BEIJING FOR THE 2008 OLYMPICS
}

\author{
XUEFEI REN \\ Michigan State University
}

\begin{abstract}
This study examines the relationship between architecture and nation building in the age of globalization, with an analysis of the debates and controversies about the National Stadium, the main sports venue for the 2008 Olympics in Beijing. The article argues that nationalism, along with the cultural ideology of global consumerism, drives the production of flagship architectural projects in China. The dilemma between nationalism and global consumerism has led state politicians and bureaucrats to opt for a global architectural language to narrate national ambitions. The study reveals the rationale underlying the search for global architecture among political elites in China, as well as its mixed consequences for local cultural discourses and politics.
\end{abstract}

$\mathbf{O}_{\text {n }}$ July 30, 2004, in the Olympic Park in north Beijing, the construction site of the National Stadium was unusually quiet. Huge machines were lying on the ground. Workers had been ordered on a two-month-long vacation. The construction of the National Stadium, which started seven months earlier in December 2003, was suddenly stopped by order of the central government. The direct cause for stopping the construction was a petition submitted to the central government by a group of academicians from the Chinese Academy of Sciences, the most distinguished academic establishment in physical sciences and architecture. In the letter, the academicians criticized the stadium design for its "extravagance, huge costs, wasteful use of steel, engineering difficulty and potential safety problems." 1 The central government responded to the petition by ordering a financial review of the project. The design of the stadium would have to be revised in order to cut down the construction costs.

The National Stadium is the highest profile architectural project among the thirty-one stadiums being prepared for the 2008 Olympics in Beijing (Figure 1). With 80,000 permanent spectator seats and another 11,000 temporary seats, the National Stadium is the central stage where the opening and closing ceremonies of the 2008 Olympics will take place. The stadium is dubbed "bird's nest" by locals, as its grid-like steel structures with interwoven twigs resemble a bird's nest. It was designed by Swiss architects Jacques Herzog and Pierre de Meuron, the laureates of the 2001

Direct Correspondence to: Xuefei Ren, Department of Sociology and Global Urban Studies Program, Michigan State University, 316 Berkey Hall, East Lansing, MI 48824-1111.E-mail: renxuefe@msu.edu.

JOURNAL OF URBAN AFFAIRS, Volume 30, Number 2, pages 175-190.

Copyright $(2008$ Urban Affairs Association

All rights of reproduction in any form reserved.

ISSN: 0735-2166. 
Pritzker Architecture Prize. Choosing these two prominent international architects reveals the ambitions among territorial elites in China to demonstrate the country's rise as an eminent economic and political power on the world stage.

Architecture is a major vehicle employed by territorial elites to negotiate national identity and express national ambitions. Deciding upon the right architectural form for large-scale state projects, such as parliament buildings, national libraries, and museums, has always been a contested issue. In the past, local elites searched for a national form that incorporated indigenous architectural elements to express distinctive national identities (Lane, 1985; Bozdogan, 2001; Xue, 2006). However, in the age of globalization, state politicians and bureaucrats have increasingly adopted a global architectural language to rebrand their cities and nations. Although using prominent architects for place marketing is not an entirely new phenomenon, it has taken on a new significance in degree, if not in kind, as cities compete for international recognition and investment (Rowe \& Kuan, 2002). This study examines the relationship between architecture and nation building under conditions of globalization, with an analysis of the debates and controversies surrounding the construction of the National Stadium for Beijing's 2008 Olympics.

The argument in this study is twofold. First, I argue that nationalism, along with the cultural ideology of consumerism, drives the production of flagship architectural projects in globalizing Chinese cities. Second, using global architecture-architectural design from a small group of elite architectural firms mostly based in the West - as a place-marketing strategy can have unexpected and mixed consequences depending on the specific power configurations of local political, economic, and cultural establishments.

This study examines both the rationale and the mixed consequences of adopting a global architectural language to narrate national ambitions. We do this by delving into the controversies surrounding the construction of the National Stadium in Beijing. The decision to use Herzog and de Meuron's design was first challenged by local cultural conservatives who were highly critical of commissioning large-scale state projects to foreign architects. To gather popular support and gain legitimacy, the new administration (2003 to present) in China responded to the criticisms by stopping the construction and revising the architectural design of the stadium. However, the government was severely criticized by cultural liberals who embraced the participation of international architects in the Olympics-related projects and criticized the administration for its inconsistent and nontransparent decision-making process. The legitimacy of the new administration was undermined in the course of using global architecture to represent China to the world in 2008.

This article is divided into four sections. The first section discusses previous studies on urban regeneration and flagship architectural projects. Although many have examined economic imperatives and the impact of flagship architectural projects, social scientists have just begun to explore the linkage between architectural mega projects and nation-building practices in global or globalizing cities. The second section analyzes Beijing's bid and preparations for the Olympics. The multiple motivations behind the decisions for bidding show that the 2008 Beijing Olympics carry higher stakes than urban regeneration. The nature of the Beijing Olympics as a national event instead of a city event explains the rationale behind central and city government officials' decisions to choose the best global architecture for the National Stadium. The third section analyzes the three stages of the controversies: the international design competition held in 2003 in which Herzog and de Meuron won the bid; the petition by conservative academicians opposing Herzog and de Meuron's design; and the campaign launched by cultural liberals criticizing the authoritarian and nontransparent decision-making process of the current political regime in China. In the conclusion, I discuss whether the theoretical insights drawn from Beijing can be applied to other urban contexts. 


\section{ARCHITECTURE, URBAN REGENERATION, AND NATION BUILDING}

This study is situated within the larger literature on urban regeneration and construction of flagship architectural projects. The shift from the Fordist to the post-Fordist flexible regime of production has significantly impacted the city (Harvey, 1990). Since the 1970s, cities have been transformed from production sites into consumption sites with strong business service and entertainment functions. In the intensified interurban competition, local governments have increasingly employed the strategy of hosting mega events and constructing flagship architectural projects to create a positive urban image to attract residents, visitors, and investment. In the process, signature designs from internationally prominent architects are especially sought after by local private and public clients in order to put their cities on the map. In the past two decades, a large number of high-profile architectural projects have been built in many global and globalizing cities.

Previous literature has examined the broader socioeconomic forces driving the construction of architectural mega projects, as well as the impact of such projects on local urban economies and governance. Focusing on cultural institutions and downtown redevelopment, Strom (2002) attributes the construction of flagship museums to the increasingly important role of consumption in urban economies, the financial imperatives of cultural institutions in the new market economy, and the blurring boundary between low and high culture. Sklair $(2005,2006)$ further connects the production, marketing, and consumption of iconic architecture to the agents of the transnational capitalist class. According to Sklair, the transnational capitalist class in and around architecture include multinational architectural firms with great delivery capacity, globalizing politicians and bureaucrats who commission and regulate architectural projects, professionals in the engineering, finance, and real estate sectors, as well as merchants and media, who are responsible for the marketing and consumption of architecture. Sklair argues that in the global era architecture tends to be driven by the transnational capitalist class of the corporate interest and by the cultural ideology of global consumerism.

In spite of the high expectations of their role as a catalyst in reviving a place, the economic impact of flagship architectural projects is largely uneven and difficult to evaluate. In many cases, the intended profit-making developments became loss-making projects (Lee, 2002; Searle, 2002; Thornley, 2002). Since the strategy of mega project construction can be easily copied from city to city, it is unlikely that a locality can achieve overall structural competitiveness from such boosterist building efforts (Jessop, 1998).

Although many have examined the economic imperatives and impact of flagship architectural projects, social scientists have just begun to explore the linkage between nationalism, political identity, and construction of architectural projects under conditions of globalization. McNeill (2000) examines the impact of globalization on European territorial politics by analyzing the debates about the opening of the Frank Ghery-designed Guggenheim Museum in Bilbao. He argues that the construction of the Guggenheim Museum is not only an economic initiative to revitalize Bilbao's deindustrialized urban economy, but also part of the political maneuver by the ruling party in the Basque region to compete with other oppositional institutions and to enhance its relative strength within Spain. In another study on the unbuilt Welsh Opera House in Cardiff Bay designed by Zaha Hadid, McNeill and Tewdwr-Jones (2003) apply the concept of banal nationalism (Billig, 1995) to analyze the symbolic intervention of territorial elites by using architectural projects to rebrand nations. Billig (1995) suggests that in affluent societies nationalism is observed in less visible forms, which he calls "banal nationalism," a presence of nationalism in everyday, mundane situations. McNeill and Tewdwr-Jones (2003) argue that new architectural projects mushrooming in Europe can be seen as vehicles of such banal nationalism, promoted by nervous European political elites in an attempt to renarrate their nations at a time when sovereignty in Europe has been rebundled and re-regulated (p. 738). Along these same 
lines, this study examines the relationship between architecture and nation building in the Chinese context.

Rapidly globalizing Chinese cities such as Beijing and Shanghai have become the wild frontiers for architectural experiments, as local government officials and real estate developers compete to commission their mega projects to internationally prominent architects. A number of studies have examined place marketing and the use of flagship architectural projects in Chinese cities (Wu, 2000; Olds, 2001; Cartier, 2002; Xu \& Yeh, 2005). Broudehoux's (2004) monograph on post-Mao Beijing goes beyond the narratives of urban regeneration and situates the construction of flagship architectural projects in China's nationalist agenda. She links Beijing's city marketing techniques and image construction initiatives in the 1990s to Chinese nationalism, and shows how state aspirations and global expectations are articulated in the creation of a world image of Beijing. Broudehoux argues that in the course of China's pragmatic market reform, the ruling Chinese Communist Party has given up some of its commitment to social welfare issues, and therefore has increasingly faced a legitimacy crisis. To regain public support, the Chinese state sought to nurture a nationalist revival by substituting patriotism for Marxism (Broudehoux, 2004, p. 10). The nationalist revival is evident in the recent reformulation of debates on China's transitional economy. The debates are more frequently framed in the dichotomy of national industry versus foreign competition, instead of socialism versus capitalism. Gallagher (2002) argues that by reformulating an economic debate that pits Chinese national industry over foreign competition, the privatization of state-owned enterprises has become acceptable because it is justified in nationalistic terms. The ruling Chinese Communist Party has therefore avoided the accusation that it has "sold out" socialism.

Urban development programs in China have to be understood in relation to the rising nationalist discourse. Hosting the Olympics and building high-profile architectural monuments are not merely urban regeneration efforts, but also attempts by the ruling Communist Party to overcome a legitimacy crisis and to consolidate the political regime. The dilemma between embracing a global consumerist ideology and rising nationalism has led state politicians and bureaucrats to employ a global architectural language to narrate national ambitions, as seen in Beijing's Olympic bid and the international design competitions for the National Stadium.

\section{BEIJING'S BID FOR THE OLYMPICS: A NATIONAL EVENT}

The commercial success of the Los Angeles Olympics in 1984 turned the Olympics into a highly profitable mega event (Whitelegg, 2000; Burbank, Andranovich, \& Heying, 2001; Preuss, 2004). Due to the Games' enormous potential for urban regeneration and image building, more and more cities around the world are showing great enthusiasm in hosting the Olympics, hoping to solve urban problems and boost growth in a relatively short period of time (Hall, 1987; Essex \& Chalkley, 1998; Hiller, 2000; Roche, 2000). Recently, the list of cities bidding for the Olympics has included not only those struggling postindustrial cities, but also established global cities such as Paris (2008 and 2012 bid), New York, and London (2012 bid). These cities view the Olympics as an opportunity to strengthen their global status in an era of growing interurban competition and to finance large-scale planned construction projects (Shoval, 2002).

It is tempting at first glance to characterize Beijing's bid for the 2008 Olympics as a strategy by the local government to better position the city in the intensified interurban competition. However, an analysis of Beijing's bid and preparations for the Olympics reveal that the 2008 Olympics involve higher stakes. In addition to the tangible economic benefits to urban growth, the symbolic significance of hosting the Olympics is what has driven the central government to support Beijing's bid. Similar to the Tokyo and Seoul Olympics for Japan and Korea, Beijing Olympics is a coming-of-age event for China. It will represent to the world China's rise as a 
new global power, backed by a dynamic national economy and consolidated under the rule of the Communist Party.

Urban politics in Beijing is strongly influenced by the central government. The bidding and preparations of the Olympics are initiated and tightly monitored by the central government. In the late 1980s, the city government of Beijing was ordered by the central government to submit an official application for the 2000 Games. In 1993, Beijing came tantalizingly close to hosting the 2000 Olympics, losing to Sydney by only two votes in the last ballot. However, the central government was determined to bring the Olympics to China. In 1998, Beijing bid again for the 2008 Games. The Beijing 2008 Olympic Games Bid Committee (BOBICO) was established in 1999. Its members included not only municipal officials, but also high-ranking politicians from the State Council and national governmental agencies in charge of cultural affairs, sports, and urban planning. In August 2000, the International Olympic Committee (IOC) officially announced Beijing as a candidate city, along with Osaka, Istanbul, Toronto, and Paris (Ong, 2004).

The BOBICO mobilized a wide range of public support for the bid. It promised the IOC that they would provide world-class stadiums for the Games. Hundreds of local architects and planners drafted designs for 32 Olympic venues. In Beijing's Olympic Candidature File, 235 out of the 596 pages are devoted to explanations of stadium design and construction. Hundreds of cultural events and programs were organized during the bidding process. In February 2001, a delegation from the IOC visited Beijing. The delegates were highly impressed by the advanced preparations and rated Beijing's bid as "excellent." Although Beijing fell far behind its rival cities in terms of environmental protection and infrastructure, the strong political support from both city and central governments convinced the IOC that Beijing would deliver what it had promised in the bid proposal. On July 13, 2001, the IOC president Juan Antonio Samaranch announced in Moscow that the host city of the 2008 Olympic Games was Beijing. ${ }^{3}$

Hosting an Olympics could push urban economic development in Beijing. As the host city, Beijing is entitled to receive a substantial amount of sales revenue from broadcasting rights and corporate sponsorship. Large domestic banks and corporations have lined up to be the capital providers in financing numerous infrastructure projects. Olympics-related investment can quickly improve transportation and telecommunication infrastructures, which the city has been desperately trying to upgrade. It can also add local amenities that the city lacks, such as sports stadiums and parks. The event can put pressure on the city government to make environmental protection its top priority. ${ }^{4}$ In addition to these tangible benefits, hosting the Olympics can build a new image of Beijing as a modern and international metropolis. The saturating media coverage before, during, and after the event will put Beijing on the world stage (Polumbaum, 2003). The government's determination to create a new image of Beijing is reflected in the official slogan of the 2008 Games: "Great Olympics-New Beijing." The government hopes that the unfolding Olympic legacy can attract global business investment and tourists to the city in the years following the Games.

In spite of these positive economic prospects, it is evident that the Olympics will pose a great challenge for Beijing's real estate market and social stability. Millions of urban homes were demolished in order to make space for Olympics-related construction. Urban residents were relocated to remote suburbs with poor infrastructure facilities. ${ }^{5}$ The pre-Olympics construction rush has led to speculation in the real estate sector. Together with the tightening of land supply by the government, real estate prices in Beijing have skyrocketed, becoming the highest in the country. There are widespread concerns about the crash of the real estate market in the postOlympics years. Moreover, the location of the Olympic Park in the well-developed north side will further widen spatial inequality within the city. Concentrated capital investment in Beijing has also impacted the already unbalanced regional development in China, as Beijing is pulling scarce resources and investment from other regions. The central government's choice of Beijing as the 
host city has sent a clear signal to Shanghai, the financial capital of China. Hosting the Olympics will inevitably intensify the rivalry between the two cities. After Beijing's successful bid, Shanghai immediately secured the right to host the World Exposition in 2010. The race between Beijing and Shanghai will further concentrate capital investment in these two cities, increasing regional inequality between the two and the rest of the country.

The city government issued a series of strategic plans for the pre-Games preparations. In July 2002, the Beijing Organizing Committee for the Olympic Games (BOCOG) issued the Olympic Action Plan. The Plan reiterated the three themes for the Beijing Olympics-Green Olympics, High-Tech Olympics, and People's Olympics. According to the Plan, the preparation period leading up to 2008 is divided into three phases: the first phase from December 2001 to June 2003 is for consolidation of supervisory organizations and preparation of facility construction. The second phase, from July 2003 until June 2006, is the peak period of facility construction. In the third period, from June 2006 to July 2008, officials would reinspect facilities and make last-minute preparations for the Games. The Plan also specified development goals in diverse fields such as environment, transportation, communication, and other civic infrastructures. The environmental improvement project is estimated to receive an investment of 86 billion dollars, in order to relocate manufacturing facilities outside the fourth ring road, build gas pipes to reduce coal consumption, and construct three green belts around the city to improve air quality. The upgrading of transportation infrastructures will require an investment of another 36 billion dollars and includes the construction of the sixth ring road, ten expressways, seven subway lines, and the expansion of Beijing International Airport. To promote the "People's Olympics," the construction of cultural institutions and historical preservation are also proposed. Dozens of brand new museums, libraries, and television stations will be built in the city. Twenty-five historical areas are identified as preservation zones. The total investment in all the preparations is estimated to exceed 200 billion dollars. ${ }^{6}$

The 2008 Olympics is no longer a sports event or even an urban regeneration effort. It is a national event and a symbolic showcase through which the central government of China intends to demonstrate to the world the country's economic achievements over the past two decades. Hosting a successful Olympics carries great weight for Beijing and China as a whole. Through various strategic plans, Beijing is gradually building up the momentum toward 2008. It is in this context that the international design competition for the National Stadium took place.

\section{GOING FOR GLOBAL ARCHITECTURE: INTERNATIONAL DESIGN COMPETITION OF THE NATIONAL STADIUM}

In order to win the Olympic bid, the political elites associated with the BOCOG and Beijing Municipal Planning Commission (BMPC) chose prime land in north Beijing for the Olympic Park. The master plan was drafted by a prominent engineering firm-Sasaki \& Associates, from the United States. The Olympic Park is strategically located on the extension of the central axis of Beijing. The central axis is 7.8 kilometers in length, starting from Yongding Gate in the south, and ending at Bell Tower in the north. All important structures, such as the Forbidden City and Tian'anmen Square, are located on this axis. In the newly planned Olympic Green of 1,135 hectares, three major sport facilities - the National Stadium, the National Gymnasium, and the National Swimming Center-will be separately located on either side of the axis. A 500-meter skyscraper will be built on the northern tip of the central axis.

From the start of the competition, the BMPC, BOCOG, and city government aimed for a prestigious international firm for the stadium. In June 2002, the mayor of Beijing announced that "Beijing would gather the best architectural designs from the world for Olympic stadiums."7 In October 2002, the city government and the BOCOG asked the BMPC to organize a competition 


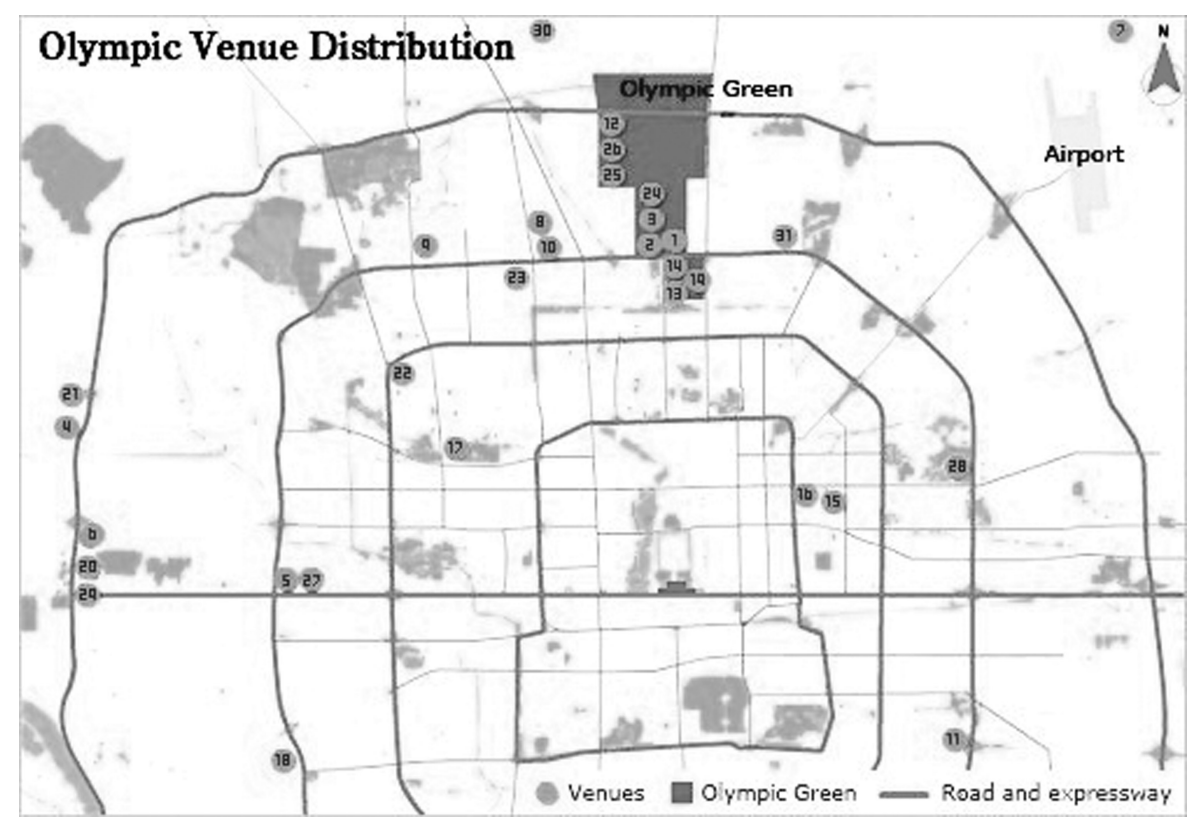

FIGURE 1

\section{Olympic Venues Planned in Beijing}

Note: From the official Website of the Beijing 2008 Olympic Games, downloaded at http://en.beijing2008. $\mathrm{cn} / \mathrm{cptvenues/venues/.}$

(1). New Venues in Beijing: 1. National Stadium; 2. National Aquatics Center; 3. National Indoor Stadium; 4. Beijing Shooting Range Hall; 5. Wukesong Indoor Stadium; 6. Laoshan Velodrome; 7. Shunyi Olympic Rowing-Canoeing Park; 8. China Agricultural University Gymnasium; 9. Peking University Gymnasium; 10. University of Science and Technology Beijing Gymnasium; 11. Beijing University of Technology Gymnasium; 12. Olympic Green Tennis Center.

(2). Existing Venues in Beijing: 13. Olympic Sports Center Stadium; 14. Olympic Sports Center Gymnasium; 15. Workers' Stadium; 16. Workers' Indoor Arena; 17. Capital Indoor Stadium; 18. Fengtai Softball Field; 19. Ying Tung Natatorium; 20. Laoshan Mountain Bike Course; 21. Beijing Shooting Range CTF; 22. Beijing Institute of Technology Gymnasium; 23. Beijing University of Aeronautics \& Astronautics Gymnasium.

(3). Temporary Venues in Beijing: 24. Fencing Hall; 25. Olympic Green Hockey Field; 26. Olympic Green Archery Field; 27. Wukesong Baseball Field; 28. Chaoyang Park Beach Volleyball Ground; 29. Laoshan Bicycle Moto Cross (BMX) Venue; 30. Triathlon Venue Urban Road Cycling Course; 31. Road Cycling Course.

of conceptual architecture designs for the stadium. The BMPC specified that the mission of the project is "constructing a large-scale stadium equivalent to the world's best practice," and that "the stadium design shall embody the new image of urban development in Beijing, and fully reflect the idea of Great Olympics-New Beijing."

The overwhelming number of international design teams and jury members reflected the globalizing tendency of the political elites in the BOCOG and BMPC. The BMPC specified a set of prequalification requirements, such as prior experience in designing large-scale stadiums, so that only those established international firms and a few large domestic design institutes qualified to compete. The invited design firms included eight foreign firms, three joint ventures, and only two Chinese design institutes. Among the thirteen jurors, six were international architects, including prominent architects such as Dominique Perrault, Rem Koolhaas, Jean Nouvel, and Kisho Kurosawa. The Chinese panel was composed of two officials from the BOCOG, one from BMPC, 
and four senior engineering experts from the Chinese Academy of Sciences. None of the Chinese jurors were architects. The predominance of international architects and Chinese officials already implied that Herzog and de Meuron would have a good chance of winning.

The BMPC listed few specific requirements for the conceptual design. However, it insisted that the stadium "shall have a retractable roof, with the configuration designed to fully reflect the characteristics of modern sports buildings." 9 The BMPC officials believed that "the stadium with a retractable roof will turn out to be a significant architectural legacy of the 2008 Olympics." 10 The retractable roof became the focus for both architects in their design process and for jurors in their evaluation. Specialist engineering firms were hired by architectural teams to design a safe and cost-effective roof. Experts carefully evaluated the feasibility of each team's roof design. However, all of these efforts turned out to be an exercise in futility as the government later ordered the retractable roof removed to cut down the cost. The design change was widely criticized by cultural liberals, who saw it as evidence of the government's inconsistent decision-making process.

Although architectural competitions are still new practices in China, the BMPC staged a professional international competition. The officials of the BMPC knew all too well that a widely publicized international design competition was no less important than the stadium itself in promoting the 2008 Olympics. From March 23 to 25, 2003, the thirteen-member international panel evaluated design proposals. The evaluation included a site visit, a presentation of the technical panel, a review of booklets, exhibition panels, and models, as well as discussions and analyses of the merits and demerits of each scheme. Herzog and de Meuron's design, the "bird's nest," won eight votes out of thirteen, the highest among all proposals. The "bird's nest" was shortlisted together with another two design schemes from Beijing Institute of Architectural Design and Research (BIAD), and a joint venture of a Japanese design firm and the local Tsinghua University. As a largely symbolic gesture, the three shortlisted design proposals went into a public exhibition for popular voting. Herzog and de Meuron's design had a thin margin of public votes over the other two.

Herzog and de Meuron's decision to enter China was triggered by Rem Koolhaas' winning of the CCTV (Chinese Central Television) building project in Beijing in 2002. Herzog and de Meuron were also invited to the CCTV competition. However, they decided not to compete after learning about the poor protection of intellectual property rights and the unfair practices of design competitions in China. In the winter of 2002, they received the news that Rem Koolhaas, their friend and rival, won the design competition. They regretted the lost opportunity and believed that if they had participated, they would have won. ${ }^{11}$

For Herzog and de Meuron-two architects based in Basel, Switzerland-China is an unfamiliar terrain. They sought advice from Uli Sigg, the former Swiss ambassador and a Chinese art collector. Uli Sigg recommended Ai Weiwei as their local consultant. Ai Weiwei is a wellestablished artist who returned to Beijing after a 10-year stay in New York. As the son of China's famous poet of the 1920s, Ai Qing, Ai Weiwei had sufficient political capital to help Herzog and de Meuron navigate complicated bureaucratic procedures and unpredictable domestic politics. Ai Weiwei first found a local design partner for Herzog and de Meuron-the China Architecture and Design Group - to build a design consortium. He also turned out to be the most outspoken advocate for Herzog and de Meuron's design when the project was later caught in a cultural war between liberals and conservatives. In April 2003, only six months after Herzog and de Meuron came to China, they were told that they won the largest trophy-the commission to design the National Stadium.

In the brief accompanying the conceptual design, Herzog and de Meuron described their design as "a collective vessel for People's Olympics." They emphasized the pure shape of the stadium, with interwoven grid-like structures "producing dramatic effects" for the stadium. Referencing 


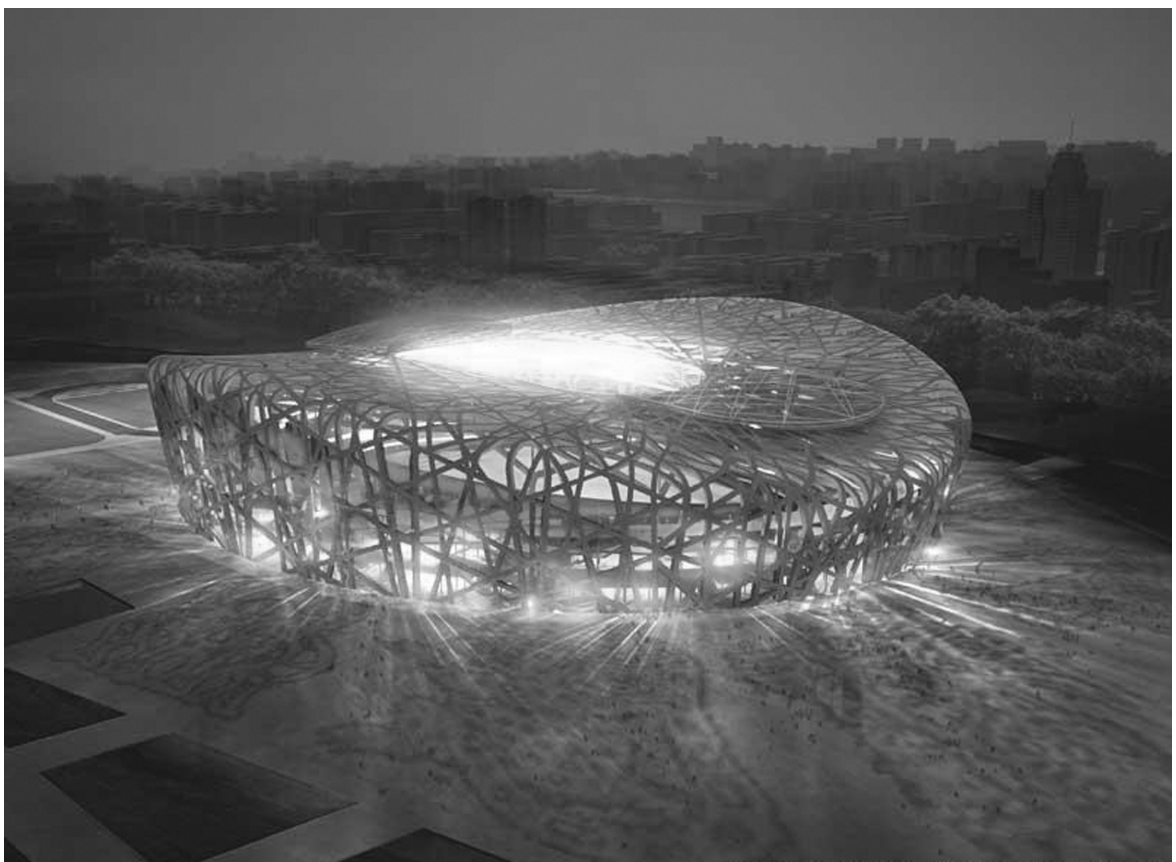

\section{FIGURE 2}

\section{Architectural Design of the National Stadium by Herzog and de Meuron}

the Eiffel Tower, they claimed that the stadium would become "a unique historical landmark for the 2008 Olympics." 12 With an unusually exposed structure that mimics a bird's nest, the design delivered the most shocking visual impact among all the proposals, capturing the votes of both the international architects and Chinese politicians. The BMPC praised the design highly, commenting that "the pure, simple and powerful building shape blends all into a harmonious whole" and that "the entire building gives a strong sense of dynamics and vigor"13 (Figure 2).

The proposed budget for the "bird's nest" was 38.9 billion RMB (roughly 500 million U.S. dollars). Although it does not exceed the budget limit of 40 billion RMB set up by the BMPC, it is well above the budget of the second design entry by BIAD, which proposed a modern stadium meeting all the Olympics' requirements with only 2.7 billion RMB, $7 \%$ of the budget as proposed by Herzog and de Meuron. Obviously, compared to the pursuit of visual impact, the budget is only of secondary concern for the BMPC.

While the design competition was going on, another separate bidding for ownership of the stadium took place. In August 2003, it was announced that a group of five firms led by CITIC (China International Trust and Investment Corp), a large state bank, was the winner of the ownership tender. CITIC will invest $42 \%$ of the total construction cost, with the remaining $58 \%$ to be provided by the city government, represented by Beijing State-Owned Assets Management Corp. The city government will also provide subsidies by reducing land leasing fees and helping with demolition. CITIC and the city government formed the National Stadium Ltd., which has thirty years of use right of the stadium after the Olympic Games. The city government will not share profits for the first thirty years, but then ownership of the stadium will revert to the city. In November 2003, a service agreement was signed between CITIC, the city government, and the Sino-Swiss design consortium. To keep up the momentum of the preparations for the Olympics, 
the BOCOG decided to start construction immediately. In December 2003, while architects were still working on preliminary design drawings, the construction of the National Stadium broke ground.

\section{POLITICS AND DEBATES SURROUNDING THE NATIONAL STADIUM}

It is not uncommon to observe controversies regarding form, function, and location of flagship architectural projects. The debates on flagship architectural projects in China are mainly focused on the nationality of architects, along with costs and aesthetics.

From 1998 to 2003, three large-scale public projects in Beijing were commissioned to international architects: the National Theatre to Paul Andreu, the National Stadium to Herzog and de Meuron, and the CCTV to Rem Koolhaas. This led to a heated debate in the local architectural community. Wu Chen, the leading opponent and son of a prominent architect in the Chinese Academy of Sciences, cynically called Beijing "the laboratory for foreign architects." ${ }^{14} \mathrm{He}$ sees the dominance of foreign architects in Chinese mega projects as a new form of cultural colonialism. Wu Chen criticized the central government for providing too much political and financial support to foreign architects who use Chinese tax payers' money for their avant-garde architectural experiments that could in no way be realized in their own countries. He argued that Chinese cities were losing their authentic character, becoming banal, homogenized cities similar to everywhere else in the world. ${ }^{15}$ These opinions are widely shared among cultural conservatives, a group of Beijing-based architects and academics who strongly oppose commissioning state-sponsored projects to foreign architects. Many of the cultural conservatives are from an older generation of architects who designed many monumental state buildings in Beijing in the 1950s. They see the participation of international architects as a threat that endangers the development of modern Chinese architecture.

In July 2004, seven months after the stadium's groundbreaking, four senior members of the Chinese Academy of Sciences submitted a petition to the Prime Minister Wen Jiabao. In the letter, the petitioners criticized the recent architectural trend in China for "ever bigger, newer, and foreign design," which they saw as leading to serious problems in safety and raising construction costs significantly. The petitioners criticized the design of the National Stadium, saying it "not only required an extraordinary use of steel, but also had potential problems in safety and stability." They wrote "such extravagant design is an unnecessary waste and risk, and will damage the Olympic preparation efforts." 16 The central government accepted the petition promptly, called the construction to a halt, and requested a financial review of the stadium.

A similar petition also by cultural conservatives was submitted in 1998 protesting Paul Andreu's design of the National Theater (Peng, 2000). Although that petition was on a much larger scale, mobilizing more than a hundred Academy members, it was rejected by the central government. The central government saw the ultra-modern design of the National Theatre as a symbol showcasing Beijing and China's progress, open-mindedness, and imagined political transparency. The project is also interpreted by critics as Jiang Zemin's (China's president until 2002) attempt to leave a personal landmark at Tian'anmen Square in the last year of his term.

However, the political climate in China has changed significantly since 1998. Domestic politics in 2004 were more favorable to cultural conservatives. Two major events happened during this period. In March 2003, Jiang Zemin stepped down as the General Secretary of the Chinese Communist Party and was succeeded by two populist politicians- - Hu Jintao as the President, and Wen Jiabao as the Prime Minister. Compared to their predecessor, Hu and Wen's administration has expended more effort winning popular support, and they see the Olympic preparations as a good political opportunity to mobilize such support. In July 2003, Wen Jiabao delivered a speech at a meeting of the State Council, declaring that the Olympic preparations must avoid extravagance 
and pay more attention to cost saving. The city government of Beijing closely followed the new retrenchment policy. In August 2004, the mayor of Beijing announced three requirements guiding stadium construction: using existing stadiums and avoiding repetitive construction, reducing construction cost, and emphasizing post-Games usage ${ }^{17}$ The retrenchment policy provided a political opportunity for senior academicians to have their voices heard. The second event was the collapse of a new terminal at Charles de Gaulle International Airport in Paris in May 2004. In the accident, two Chinese passengers were killed. The airport terminal was designed by Paul Andreu, the same architect who was commissioned to design the National Theatre. The accident triggered a wide range of suspicions in Beijing regarding the safety of foreign-designed buildings, and it provided an immediate catalyst for the order to stop the construction of the National Stadium. ${ }^{18}$

After a financial review by the central government, the original budget of $\$ 500$ million was cut down to \$325 million, and then to \$290 million. According to an interview with Li Xinggang, the chief architect and local partner of Herzog and de Meuron, the budget cut was "like squeezing a wet towel—when the budget was reduced from $\$ 500$ to $\$ 290$ million, there's no water to squeeze anymore, and we had to cut features of the design."19 A panel of domestic structural engineers made the final decision on the design change-removing the retractable roof. This saved 15,000 tons of steel and $\$ 50$ million. Herzog and de Meuron were content with the design change. The roof would have been an engineering triumph, but without it, the overall form became more consistent and powerful (Lubow, 2006). CITIC initially complained about removing the roof, as it might affect the operation of the stadium in bad weather. However, CITIC did not insist on having the roof after the government adopted the new retrenchment policy. Although the government's decision did not spark strong opposition either from CITIC or from the architects, it became the focus of criticism from local cultural liberals who questioned the inconsistent and nontransparent decision-making process of the authoritarian regime.

\section{IMPORTING GLOBAL ARCHITECTURE AND ITS MIXED CONSEQUENCES}

The cultural liberals are a group of architects, artists, journalists, and academics in Beijing who embrace and collaborate with international architects. Many of them are from a younger generation who have studied abroad and have extensive connections with overseas architectural firms, schools, and cultural institutions. They have played a crucial role in introducing international architects to China and helping them win design competitions. This section examines the narrative of the critiques by analyzing the meeting memo of a discussion forum held by the cultural liberals.

On August 20 of 2004, approximately twenty Beijing-based prominent artists, art critics, and architects held a discussion forum about the new developments of the National Stadium. The organizers intended the meeting to be a platform for this small circle of cultural elites to freely express their opinions on the government intervention in the construction of the National Stadium. Although the media was not present at the meeting, many of the opinions and speeches from the meeting were later widely circulated on the Internet, and played an important role in guiding public opinion on the events surrounding the stadium. The criticisms were mainly focused on three subjects: the negative impact of this event on the development of contemporary Chinese architecture, the problematic powerful lobby by senior Academy members, and the inconsistent and contradictory decision-making process of the central government.

The concern over the negative impact this would have on China's architectural development was shared only by professional architects. They saw the original retractable roof as an engineering triumph and a technological breakthrough. They compared it to early skyscrapers in New York and the Eiffel Tower in Paris. They argued that new architectural projects like the National Stadium "have posed new challenges to contemporary architectural development, and in the meantime are 
trying to offer possible solutions." They saw the revision of the design as a lost opportunity to experiment with new engineering technologies.

However, this professional concern was not shared by other cultural critics at the meeting, who were more aware of the larger issues that the event implied. For them, the event revealed the illegitimate dominance in urban planning by senior academicians and the nontransparent and inconsistent decision-making system of the government. Some questioned the qualification of the academicians who submitted the petition. Others called the act of the academicians "conservative, reactionary, backward-looking, and a kind of blind patriotism," and "not the proper way to get things done." For them, the petition was not about cost saving, technology, or the retractable roof, but it symbolized "the clash of old and new cultural forces." As one critic put it, "I felt it was a revival of old and evil forces, a very conservative force trying to kill the new culture."

The most frequently appearing theme in the discussion was the decision-making process of the government. Many saw the controversy as a result of the "system" (tizhi, in Chinese), namely, the current authoritarian decision-making process characterized by inconsistency and nontransparency. Some people questioned the government's act of cutting the costs of Olympics projects in order to gain popular support. As Ai Weiwei argued, "if we only want to cut the costs, why bid for the Olympics and build the National Stadium at all? What the government is doing is quite self-contradicting." Others argued that "policy makers should be consistent, and keep what they've promised." It was agreed by the group that "it is OK to cut costs, but it has to be based on scientific analyses, instead of ad hoc decisions." The various criticisms were well summarized in Ai Weiwei's following comment.

Our society is not yet a democratic society. The decision making process has many remnants from the feudal society. The petitioners do not reveal their names, and they don't tell the media what they wrote in the letter to the State Council. This is still the 'black-box' way of doing things... when decision-makers make their decisions, what are the criterion, value and standards? I think China must change the current decision making process controlled by big powers instead of people.

For these liberal cultural elites, China cannot make progress without opening up. Economic reforms need to be accompanied by reform of the political system. Global competition and influences - both within architecture and beyond - can change ways of doing politics and redistribute power from the top down to the people. The controversies over the National Stadium have made a significant impact on other mega projects planned for the Olympics, such as the CCTV, national museums, and libraries. The debates on the cost, location, and the nationality of architects for these projects have since developed beyond the small circle of cultural elites to the general public through the Internet.

\section{CONCLUSION AND DISCUSSION}

By analyzing the controversies surrounding the National Stadium, this study shows that nationalism, along with the cultural ideology of global consumerism, drives the production of flagship architectural projects in Beijing. The dilemma between nationalism and global consumerism has led state politicians and bureaucrats to opt for a global architectural language to narrate national ambitions. The case study of the National Stadium reveals the rationale underlying the search for global architecture among political elites in China, as well as its mixed consequences for local cultural discourses and politics.

China might be a particular case in terms of strong intervention of the state in urban policy making. However, the use of flagship architectural projects for nation (re)building is evident in 
other contexts as well. A few studies discussed in the beginning of the article provide examples on the linkage between architecture and nationalism in Europe (McNeill, 2000; McNeill $\&$ Tewdwr-Jones, 2003). The generic and noncontextual global architecture has a wide appeal among territorial elites eager to construct a globally oriented image for their nations and cities. In Europe, it might be the uncertainty and anxiety about economic globalization felt by political elites that account for the construction of monumental architectural projects. While in China, it is the rising nationalism, along with global consumerist ideology, that drives the production of architectural mega projects.

As most urban China studies are focused on Shanghai, it is necessary here to discuss to what extent the theoretical insights drawn from Beijing are relevant to Shanghai. Beijing and Shanghai are similar in their approaches to using flagship architectural projects for place marketing. Shanghai predates Beijing in commissioning major public projects to international architects, as seen in the development of the Pudong financial district (Olds, 2001). However, commissioning highprofile public projects to foreign architects did not lead to major controversies in Shanghai. The different results have to be understood in relation to the status of the two cities within China, the interaction patterns between central and municipal governments, the unique composition of the local intellectual community, and the global penetration of the local architectural design market.

The status of Beijing as the capital of China significantly raises the stakes and symbolic importance of large-scale public projects in the city. Unlike municipal projects in Shanghai, the national stadiums, museums, and libraries currently under construction are widely viewed as architectural icons symbolizing China in the twenty-first century, and therefore, can easily become subjects for debates and criticisms. Unlike Shanghai, the decision-making process in Beijing is strongly influenced, regulated, and penetrated by the central government. In the case of the National Stadium, direct intervention from the central government became the target of criticism from cultural liberals. There is also a larger and more active intellectual community in Beijing than in Shanghai. The Chinese Academy of Sciences, major leading architectural journals, institutes, and publishing houses are all based in Beijing. The cultural elites affiliated with these institutions actively participated in the debates. Finally, the architectural design market in Beijing was less open to foreign competition than the market in Shanghai, and therefore, the decision to commission the National Stadium to foreign architects came as somewhat of a shock to many local architects.

Although urban development programs in Shanghai are less politicized and resemble the placemarketing strategies in the West, numerous cases show that nationalism is reworked throughout urban redevelopment in Shanghai as well. One recent example would be the controversies over the design of the World Financial Center financed by the Mori Group from Japan. The delay of the project was partly due to popular protests against an architectural design that resembled a Japanese flag and a samurai sword.

Similar to other Olympics hosted by Asian countries, the 2008 Beijing Olympics is a comingof-age event for China. In 1964, the Tokyo Olympics demonstrated to the world that postwar Japan had reemerged as a new economic power. In 1988, the Seoul Olympics represented South Korea as a prosperous and dynamic country on its way to political democracy. In a similar fashion, the Beijing Olympics is a much anticipated event for the Chinese state to demonstrate the remarkable progress achieved in the past two decades of market reform. The Beijing Olympics is an engine driving economic growth and a catalyst to boost nationalistic sentiments. However, unlike Tokyo and Seoul where the main Olympic stadiums were designed by local architects (Kenzo Tange and Soo Geun Kim, respectively), state politicians and bureaucrats in Beijing approached two prominent international architects to decorate their main stage of spectacles. The paradox of nationalism and the impulse to embrace international architects well illustrate the 
changing relationship between architecture and nation building under conditions of globalization. Global architecture has become the national expression.

ACKNOWLEDGMENT: The author wishes to thank the four anonymous reviewers and the editor of the Journal of Urban Affairs who provided detailed and constructive comments for the revision. Earlier drafts of this article were presented at the North American Chinese Sociological Association, Montreal, Canada in August 2006, and at the Workshop on Built Environment at the University of Chicago in October 2006.

\section{ENDNOTES}

1 From Wu, C. G. (2004). Beijing aoyun shoushen diaocha (Beijing Olympics "Diet” report). In Nanfang Daily, August 12, 2004.

2 From http://en.beijing2008.cn.

3 According to Polumbaum (2003), Beijing's winning of the 2008 Games also came at a time period when the legitimacy of the IOC was in crisis after the Salt Lake City bidding scandal. By choosing Beijing, a non-Western city in a developing country, the IOC attempted to build a new Olympic image by emphasizing diversity, transparency, and multiculturalism.

4 From Beijing Organizing Committee for the Games of the XXIX Olympiad (2002). Olympic Action Plan. Retrieved on July 4, 2006, from www.beijing*2008.org/new_olympic/eolympic/plan.htm.

5 The popular protests against forced demolition have become a major source of social unrest in Beijing and other Chinese cities. For example, the site of the Olympic Park was occupied by thirty-three state enterprises, 721 collectives, and 5,700 households. The demolition started in August 2002. It took only four months to relocate all the households and enterprises. A total of 2.19 million square meters of existing structures were demolished. The statistics were released by Beijing Municipal Bureau of State Land and Resources in November 2002. See http://www.bjgtj.gov.cn.

6 From Olympic Action Plan (2002).

7 From Wu (2004).

8 From Beijing Municipal City Planning Commission (2004), The National Stadium, p. 9.

9 Ibid, p. 21.

10 Ibid, p. 37.

11 From the interview with Ai Weiwei, the artistic consultant for Herzog and de Meuron.

12 Olympic Action Plan (2002), p. 57.

13 Ibid, p. 53.

14 From Wu (2005) Beijing: Waiguo jianzhushi de shiyanchang (Beijing: A Laboratory for Foreign Architects). In South China Weekly, May 29, 2005.

15 From Wu (2005).

16 From Wu (2004).

17 The speech was delivered at the Seventh Plenary Session of the Ninth Beijing Committee of the Communist Party of China, July 24-25, 2004, Beijing. The document can be retrieved at http://news.xinhuanet.com/ newscenter/2004/08/03/content_1695377.htm.

18 The new retrenchment policy had repercussions on other Olympic stadium projects. The number of stadiums to be newly built was reduced from nineteen to twelve. The number of stadiums to be renovated was reduced from thirteen to eleven. All other facilities will be temporary structures. 
19 From the meeting memo of Forum on Olympic Architecture and Mega Projects in Beijing. The forum was held on August 24, 2004. The author was not present at the meeting, but secured the complete meeting memo (37,145 words) from one participant of the meeting. Later the author interviewed a few participants. Other quotes in this section are from the same document.

\section{REFERENCES}

Beijing Municipal Planning Commission (2004). The National Stadium competition of the architectural concept design. Beijing: China Architecture \& Building Press.

Beijing Organizing Committee for the Games of the XXIX Olympiad (2002). Olympic action plan. Retrieved (July 4, 2006) from http://www.beijing2008.org/new_olympic/eolympic/plan.htm.

Billig, M. (1995). Banal nationalism. Thousand Oaks, CA: Sage Publications.

Bozdogan, S. (2001). Modernism and nation building: Turkish architectural culture in the early republic. Seattle, WA: University of Washington Press.

Broudehoux, A. M. (2004). The making and selling of post-Mao Beijing. New York: Routledge.

Burbank, M., Andranovich, G., \& Heying, C. H. (2001). Olympic dreams: The impact of mega-events on local politics. Boulder, CO: Lynne Rienner Publishers.

Cartier, C. (2002). Transnational urbanism in the reform-era Chinese city: Landscape from Shenzhen. Urban Studies, 39(9), 1513-1532.

Essex, S., \& Chalkley, B. (1998). Olympic Games: Catalyst of urban change. Leisure Studies, 17(3), 187-206.

Gallagher, M. (2002). Reform and openness: Why China's economic reforms have delayed democracy. World Politics, 54(3), 338-372.

Hall, C. (1987). The effects of hallmark events on cities. Journal of Travel Research, 26(2), 44-45.

Harvey, D. (1990). The condition of postmodernity. Oxford: Blackwell.

Hiller, H. (2000). Mega-events, urban boosterism and growth strategies: An analysis of objectives and legitimations of the Cape Town 2004 Olympic bid. International Journal of Urban and Regional Research, 24(2), 439458.

Jessop, B. (1998). The narrative of enterprise and the enterprise of narrative: Place marketing and the entrepreneurial city. In T. Hall \& P. Hubbard (Eds.), The entrepreneurial city: Geographies of politics, regime and representation. New York: Wiley.

Lane, B. M. (1985). Architecture and politics in Germany, 1918-1945. Cambridge: Harvard University Press.

Lee, P. (2002). The economic and social justification for publicly financed stadia: The case of Vancouver's BC Place Stadium. European Planning Studies, 10(7), 861-873.

Lubow, A. (2006). The China syndrome. The New York Times, May 21, 2006.

McNeill, D. (2000). McGuggenisation? National identity and globalisation in the Basque country. Political Geography, 19(4), 473-494.

McNeill, D., \& Tewdwr-Jones, M. (2003). Architecture, banal nationalism and re-territorialization. International Journal of Urban and Regional Research, 27(3), 738-743.

Olds, K. (2001). Globalization and urban change: Capital, culture and Pacific rim mega-projects. Oxford: Oxford University Press.

Ong, R. (2004). New Beijing, Great Olympics: Beijing and its unfolding Olympic legacy. Stanford Journal of East Asian Affairs, 4(2), 35-49.

Peng, A. P. (2000). Why do we strongly oppose the French architect's scheme of the Grand National Theatre? Architectural Journal, 11, 11-12.

Polumbaum, J. (2003). Capturing the flame: Aspirations and representations of Beijing's 2008 Olympics. In C. C. Lee (Ed.), Chinese media, global contexts (pp. 57-75). London and New York: Routledge Cruzon.

Preuss, H. (2004). The economics of staging the Olympics: A comparison of the games, 1972-2008. Northampton, MA: E. Elgar.

Roche, M. (2000). Mega-events and modernity: Olympics and expos in the growth of global culture. London and New York: Routledge.

Rowe, P. G., \& Kuan, S. (2002). Architectural encounters with essence and form in modern China. Cambridge: MIT Press.

Searle, G. (2002). Uncertain legacy: Sydney’s Olympic stadiums. European Planning Studies, 10(7), 845-860. 
Shoval, N. (2002). A new phase in the competition for Olympic gold: The London and New York bids for 2012 games. Journal of Urban Affairs, 24(5), 583-599.

Sklair, L. (2005). The transnational capitalist class and contemporary architecture in globalizing cities. International Journal of Urban and Regional Research, 29(3), 485-500.

Sklair, L. (2006). Iconic architecture and capitalist globalization. City, 10(1), 21-47.

Strom, E. (2002). Converting pork into porcelain: Cultural institutions and downtown development. Urban Affairs Review, 38(1), 3-21.

Thornley, A. (2002). Urban regeneration and sports stadia. European Planning Studies, 10(7), 813-818.

Whitelegg, D. (2000). Going for gold: Atlanta's bid for fame. International Journal of Urban and Regional Research, 24(4), 801-817.

Wu, C. G. (2004). Beijing aoyun shoushen diaochao (Beijing Olympics diet report). Nanfang Daily, August 12 , 2004.

Wu, C. (2005). Beijing: Waiguo jianzhushi de shiyanchang? (Beijing: A laboratory for foreign architects?) South China Weekly, May 29, 2005.

Wu, F. (2000). Place promotion in Shanghai, PRC. Cities, 17(5), 349-361.

$\mathrm{Xu}, \mathrm{J} .$, \& Yeh, A. (2005). City repositioning and competitiveness building in regional development: New development strategies in Guangzhou, China. International Journal of Urban and Regional Research, 29(2), 283-308.

Xue, C. (2006). Building a revolution: Chinese architecture since 1980. Hong Kong: Hong Kong University Press. 